\title{
Research on Names' Implications of Hawthorne's the Scarlet Letter
}

\author{
Ke Zhang ${ }^{1}$ \\ ${ }^{1}$ Huanghuai University, Zhumadian, Henan Province, 463000 \\ 346591653@163.com
}

KEYWORDS: Hawthorne; The Scarlet Letter; Names' Implication

\begin{abstract}
In the19th century, American writer Nathaniel Hawthorne was good at romanticism, especially good at nomenclature characterization, highlighting themes. His masterpiece, "The Scarlet Letter" will epitomize this characteristic. In this novel, Hawthorne integrated the use of the Greek mythology, biblical allusions, homophonic, meaning to the word mentioned, the first letter and word form implied approximation and other methods to give four main characters names, so that this novel contains multiple moral and pluralistic themes. Hester Prynne, the heroine's name contains a beautiful, passionate, reckless and desire, at the same time it purifies the soul of humanity exploration and other significance. Arthur Dimmesdale, the hero's name contains a man commits adultery due to his cowardice and the evil hidden in the dark heart of Italy. Hester's husband Roger Chillingworth's name implies the tomb of the villain, vengeance and cold and represents of evil side of human nature, but there are also still recognition side. Hester and Arthur's daughter Pearl's name has other precious, beautiful and pure side of human nature, forming obvious contrast with her parents' $r$ evil side of human nature, encouraging them to do good deeds, so as to achieve the moral goal advocated by Hawthorne.
\end{abstract}

\section{Introduction}

In the early 19th century, the United States has entered a critical period of cultural renaissance, a variety of new thoughts new ideas emerged. Among them, the Puritan transcendental philosophy and mysticism, etc. thoughts were the most prevalent. As an American writer living in such a special period, Nathaniel Hawthorne was undoubtedly influenced by these ideas. He began the deep exploration of the relationship between time and destiny of human beings. On the one hand, Hawthorne realized human nature severely repressed by hypocritical Puritan doctrine was destroying people's happy life; and on the other hand, he could not completely get rid of deeply rooted traditional cultural thought. Such cultural contradictions made Hawthorne's life become uncertain. He could not find a reasonable way to change the reality of the society into the ideal of social perfection. In order to fully reflect his personal values of uncertainty, Nathaniel Hawthorne only borrowed symbolism to express his confused state of his mind, because symbolism could make his works have multiple interpretations.

Therefore, while creating The Scarlet Letter, Hawthorne used cultural creative approach known as symbolism to convey more contradictory meanings to induce the reader's imagination, and express thought-provoking thoughts and feelings. As a master of symbolism, Hawthorne has given the four major characters' names in The Scarlet Letter colorful symbolic implications to express their uncertain values. This thesis will conduct brief analysis of the implicated moral values conveyed by the four main characters' names. 


\section{The Implication of Hester Prynne}

Hester Prynne is one of the four main characters portrayed Hawthorne deliberately. she is a character with a variety of symbolism. People only need take note of her name and then roughly guess her image and personality. Hester has two meanings. First, Hester reminds the reader of Greek mythology Hestier. Hestier is the sister of Zeus, Cronus and Rhea's eldest daughter, is a stove in charge of all the beauty of heaven and earth goddesses. In the The Scarlet Letter, Hawthorne made such a vivid portrayal of Hester: tall stubborn young woman long, slim and shapely figure, a black smooth show divergence draped shoulders. Skin fresh face charming, as well as that curved crescent and black shining eyes made it difficult to forget...Hester married in such a hasty way that the marriage was more like a spiritual adventure. It is because of this reckless, she initially married to a man about to aging, a physical deformities scholar. Due to this reckless decision, Hester initially married to an aging scholar with physical deformities. He was keen on judgments books, indifferent to Hester. Therefore, Hester this beautiful family goddess, who could not lead a normal family life, have been living in solitude and sexual inhibition. Hester was unwilling to sacrifice religious passion, daring in love with her vicar Arthur Dimmesdale. Her love for Dimmesdale was driven by passion, but also from the rash rather than imprudent behavior. She boldly issued love signals to Dimmesdale and captured this fanatical religious believers with her beauty and passion.

\section{The Implication of Arthur Dimmesdale}

Reverend Arthur Dimmesdale is the hero of The Scarlet Letter. He is a young saint, a learned orthodox theologian. Arthur reminds the reader of Adam, who committed the original sin of human ancestor. Adam could not help stealing the forbidden fruit in the Garden of Eden with Eva (Eve) because of the temptation, who were expelled from the Garden of Eden God. So what is the sin committed by Arthur Dimmesdale? Arthur Dimmesdale two initials AD is exactly Adultery (adultery) two initials, which tells us Arthur Dimmesdale is an adulterer. Although Dimmesdale is a religious fanatic, but after all he is made of flesh and blood. Deviant thoughts occasionally captured him, although the struggle between his mind and flesh was fierce, but in end he could not resist the temptation and desire to violate the commandments.

Surname Dimmesdale also contains abundant meanings. For example, Dim means weak, dark and so on. Dale means valley which always refer to open-minded people. Here, dimdale actually indicates a symbol of the original condition in a pastor's dim interior (dark heart). Dimmesdale was in love with Hester, but he could only demonstrate his love with a dark place in the forest. He could not bear the humiliation suffered by Hester caused by their immoral love, but he always tried to hide their sins in their dark hearts. He regretted his deterioration, would like to open their own crimes, but the cowardice deep inside his heart made him lose courage. He deplored his hypocrisy, but was still unable to escape from aching inside his heart. This inner struggle tortured him to look haggard, dying. Finally he put the hidden evil at heart available to the public, but it was too late, that's why he the paid a heavy price. Through the tragedy of this poor priest, Hawthorne summed up such a moral lesson: be honest, be sincere — it must be sincere. The day has eyes, the night has ears.

\section{The Implication of Roger Chillingworth}

Since Roger Chillingworth directed to a merciless revenge, it is easy to see him as a villain cruel monster. In fact, his name also contains evil side of human nature. Let's take a look at his name 
Roger. Roger has two meanings. First, Roger is a rogue (scoundrel, rogue) homonym. Roger Chillingworth is

indeed a villain. As Hester's husband, he spent his time on his wine books, and neglected his young and beautiful wife. He was conscious that he was about to aging as well as his physical deformities, but delusions of knowledgeable talent could conceal the physical defects. He did not marry his wife Hester for love, but he just let her light and desolate lonely hearts lodge in lack married stove. It is this villain personality that ruined young and beautiful Hester, and led to Hester's later tragedy. Vendetta is a typical feature of pirate treasure hunters. Roger Chlillingworth also acted as treasure hunters. He did not love his wife and have no common language with her, but when he learned that his wife's infidelity, he was still willing to do anything to revenge, because this represented his desire to rule and conquer. Try to defend the ethics of Puritan society. The treasure Roger Chlillingworth wanted to explore is not the ordinary treasure searched by pirates, but the pastor's hidden secrets. He changed his name and appeared in Boston to destroy the enemy. Roger Chlillingworth instinctively felt young priest was an adulterer, so he disguised as a physician and one of the most reliable friend, tracking a poor priest anywhere, and he was determined to dig out the secrets of hidden deep inside the heart of the pastor. He looked like a miner digging the poor pastor's heart, or rather, like a gravedigger digging into a grave, who had intended to find funerary jewelry.

\section{The Implication of Pearl}

Pearl is Hester's daughter, the crystallization of the love between Hester and Arthur Dimmesdale. This name implies three meanings. First, the name comes from the "Bible", meaning a very precious thing. "Maxiu Fu tone" has recorded such a story: Jesus allows a merchant to sell all their possessions to buy a jewelry, and said that the jewelry is prematurely country. In this novel, Hester paid a heavy price for Pearl - her reputation and life. Thus, in the eyes of Hester, Pearl occupies a very important position. Hester named her daughter Pearl not only because she looked white and tender juicy, but means precious. Hester devoted herself to bring up Pearl, the child is all that she possessed. Secondly, Pearl also means an outstanding person, a leader, cream, etc. Last but not least, Pearl is indeed a masterpiece of nature. She is adhering to the mystery of God and born of a desire at the time of the fire burning. It also stands for open flowers that will never fade.

Pearl who was full of energy, a whirlwind of passion, rich imagination, wild habits and contempt for all spirit of resistance has a perfect body. Her birth was an insult to puritan regulations. Hawthorne has used a variety of metaphors to depict the image of Pearl. Pearl sometimes likes a trace of light and sometimes likes a happy bird. Pearl represents a kind of spirit and hope of the United States, and her happy ending symbolizes the bright future of mankind.

Again, Pearl is Pearl (creek) homonym. On the relationship between Pearl and forest creek, the book made such a description: the stream of life are spent in the forest, it's experience is so murky gloomy, people could not help but want to pour out, and in addition, it no other can tell. Pearl's life is similar to a little creek, because they both have gushed from a mysterious fountain, passing through the same dark place. Just as there is no source and flowing creek in the forest as in the shadows, Pearl's life experience is also very mysterious, but she could only belong to the forest. Since Pearl was born due to adultery, she became the world's outcast children, who could only play in the woods near the creek. As a crystal clear creek, Pearl played two important parts in the novel. First, she was the painful witness of the love between Hester and Dimmesdale. She was born in the darkness of the prison, from the outset, and the mother in the scaffold humiliated hut on the island with his mother shared a long period of lonely life. Pearl saw her mother and pastor in love but 
difficult to combine in the forest. Second, just as pure stream can reflect out of the shadow of people, she is ever-present reminder of the sin committed by Hester and Dimmesdale, prompting them to purify the guilt hidden in their soul. In the forest, Pearl took Dimmesdale's hand and put it on her mother chest where the scarlet letter A existed. This habitual action has various implications. It not only reminded Hester and Dimmesdale of the sin committed by them, but also play an important role in the final stage.

\section{Conclusion}

Through the above analysis of The Scarlet Letter four main characters' symbolic names, we can not help but regard Hawthorne as the master of symbolism. Hawthorne's symbolism permeates the form and content of the novel. His clever use of symbolism indicates that he is both a critic of Puritanism and also a successor, reflecting ambivalent view of American society. Hawthorne's symbolic applications had a profound impact on the readers immersed in these symbolic images created by the fantasy world. Therefore, Hawthorne is a prophet and master of symbolism in the literary history of mankind.

\section{REFERENCE:}

[1] Barbour James. Romanticism: Critical Essays in American Literature [M], New York: The Macmillan Press Ltd, 1984: 226-265.

[2] Huang Fang. Hawthorne \& The Scarlet Letter [J], Foreign Literature,2007(7): 16-19.

[3] Ji Xiaoyuan. History Sister Discussion \& Scarlet in Qilin Worth and Pearl Image Origin [J], Xi'an International Studies University, 1998(2): 11-14.

[4] Bo Xiang. The Anglo-American Classic Novel Appreciation [M], Wuhan: Wuhan University of Press, 2005: 310-324.

[5] Arlin Turne. Nathaniel Hawthorne: A Biography [M], New York: Barnes \& Noble, Inc, 1961: 106-109. 